\title{
The Effects of Parent Education on Perceptions of Augmentative and Alternative Communication
}

\author{
Sangmin Kim ${ }^{\mathrm{a}}$, HyunJu Park ${ }^{\mathrm{b}}$, Sangeun Shin ${ }^{\mathrm{c}}$ \\ ${ }^{a}$ Graduate Program in Speech-Language Pathology, Chungnam National University, Daejeon, Korea \\ ${ }^{b}$ Division of Speech-Language Pathology, Gachon University, Seongnam, Korea \\ 'Department of Speech-Language Pathology, Chungnam National University, Daejeon, Korea
}

\author{
Correspondence: Sangeun Shin, $\mathrm{PhD}$ \\ Department of Speech-Language Pathology, \\ Chungnam National University, 99 Daehak-ro, \\ Yuseong-gu, Daejeon, 34134, Korea \\ Tel: +82-42-821-6392 \\ Fax: +82-42-823-3667 \\ E-mail: sashin@cnu.ac.kr
}

Received: October 5, 2021

Revised: November 26, 2021

Accepted: November 29, 2021

This paper was revised and supplemented part of the Master's thesis of the first author (2020).
Objectives: Parents' incomplete knowledge of AAC is apt to make them believe in misconceptions about AAC, which hinders them from having the appropriate interventions for their children. Considering the fact that parents' perception of AAC has a large impact on $A A C$ intervention, this study aims to examine the effects of parent education on the perception of AAC. Methods: Twenty-five mothers of children with complex communication needs participated in the study. Parent Education is designed as a 40-minute program consisting of (1) introduction to AAC, (2) exploring AAC systems, (3) developing linguistic competence using AAC, (4) tips for using AAC at home, and (5) policies and financial support. Extra time for question-and-answers was provided to each participant. To measure the effect of parent education on parents' AAC perception and the relationship of participants' change in perception with their satisfaction with the education program, two types of survey questionnaires were developed. Results: The repeated measured ANCOVA showed that the difference between the total scores of pre-and post-surveys was significant. The Spearman's rho was .443, indicating a moderate positive correlation between the degree of satisfaction and the change in AAC perception. Conclusion: This study showed that parent education had a positive effect on parents' perceptions of AAC overall. In particular, there was a significant change of opinion in the misconception that children must have intact cognitive skills to use speech-generating devices, the idea which showed the lowest scores in the pre-survey. It seems that the education program which focused on correcting misconceptions about AAC and providing relevant information and opportunities to use AAC devices helped to lead to these positive effects.

Keywords: Augmentative and alternative communication, Parent education, Perception
Parents' participation in augmentative and alternative communication (AAC) has been emphasized (Huer \& Lloyd, 1990). Parents of children with complex communication needs (CCN) play an important role as informants in AAC evaluation and interventional goal setting, in addition to taking responsibility for implementing AAC in practice in their daily life (Granlund, BjÖrckÅKesson, Wilder, \& Ylvén, 2008; Marshall \& Goldbart, 2008; Park, 2020, 2021). Their involvement in the overall AAC decision-making process can lead to successful use of AAC by their children (Kent-Walsh, Binger, \& Hasham, 2010; Seligman-Wine, 2007; Thun- berg, Sandberg, \& Ahlsén, 2009).

However, thier attitudes about AAC intervention range from acceptance to rejection or abandonment of AAC systems (Baxter, Enderby, Evans, \& Judge, 2012; Johnson, Inglebret, Jones, \& Ray, 2006; Moorcroft, Scarinci, \& Meyer, 2019; Park, 2020; Park, Lee, \& Park, 2020). Parents who accepted AAC treatment approaches for their children are more committed to interventions (Golbart \& Marshall, 2004; McNaughton et al., 2008; Parette Jr, Brotherson, \& Huer, 2000). These parents take an active role in determining the AAC device options and setting up the intervention goals, and 
they actively participate in promoting their children's AAC use in their daily lives (Marshall \& Goldbart, 2008). Conversely, parents with a negative attitude and an incomplete knowledge are apt to believe in misconceptions about AAC, and often prefer to rely only on traditional treatment approaches to improve their children's speech production. Past experiences with less than successful AAC interventions can also influence parents' attitudes (Moorcroft et al., 2019). Some common misconceptions described by Romski and Sevcik (2005) include: that AAC may hinder children's speech development; that it should only be considered when other treatments have proven ineffective; and that only children with normal cognitive abilities can use speech-generating AAC devices. Such misconceptions increase the chance of missing the critical point for providing appropriate interventions for the child (Cress \& Marvin, 2003).

According to previous studies conducted in Korea, parents of children with disabilities generally lacked understanding and information about AAC, and therefore needed specialized education and service programs to utilize AAC. For example, Lim, Park and $\mathrm{Ku}$ (2013) conducted individual and focus group interviews with 10 parents of children with developmental disabilities. The reasons for the difficulty in accepting AAC were the lack of information and data on AAC, the negative perception of special education teachers, and lack of professionalism, etc. Oh (2018) also found that there was a lack of information and negative perceptions about AAC through in-depth interviews with mothers of children with disabilities who are not using AAC. In addition, Shin and Lee (2016) confirmed that parents of students with disabilities had low awareness and support for AAC. They argued that parent education, expert training, and the strengthening of public relations were necessary to raise awareness. In particular, several studies showed that there was a high demand for AAC device-related information and education (Angelo, Jones, \& Kokoska, 1995; Bailey, Parette Jr, Stoner, Angell, \& Carroll, 2006; McNaughton et al., 2008; Park et al., 2020).

In this regard, the role of speech-language pathologists (SLPS) in providing AAC training and information for parents and families is emphasized (Baxter et al., 2012; Moorcroft et al., 2019). This is not only needed while AAC assessment and intervention services are being provided to the child, but also prior to providing services to correct any misconceptions the parents may have. The importance of SLPs' role in educating parents is particularly emphasized in countries including Korea in which awareness of AAC has not yet been established due to insufficient and inaccurate information provided to them. Thus, giving parents the opportunity to obtain information regarding AAC (e.g., definition, purpose, candidates, types of AAC systems, AAC use strategies, policies and funding etc.) through online or offline seminars or individual education program can be helpful to them. In particular, parents who lack opportunities to become familiar with AAC devices have a particular need to be educated on how AAC communication works. Having them experience AAC devices can help them integrate their family values, routines, and preferences into the decision-making process of selecting the most appropriate AAC device and options for their children. In this way, they may gain a sense of ownership and the motivation to make full use of AAC systems (Jones, Angelo, \& Kokoska, 1999; Moorcroft et al., 2019; Parette Jr et al., 2000).

To provide evidence about the effect of parent education on AAC perception, this study developed the parent education program which focused on correcting misconceptions about AAC, providing relevant information, and having device trials. The specific research aims are, (1) to determine whether there is a significant difference in the AAC perception scores between pre- and post-education, and (2) to examine whether there is a significant relationship between satisfaction with the program and change in the AAC perception scores.

\section{METHODS}

\section{Participants}

Twenty-five Korean mothers of children with spoken language challenges participated in this study. After sending an official letter related to the research to disability-related institutions in Daejeon City, the primary researcher recruited participants through telephone and e-mail. The mean age of mothers was 39.12 years $(\mathrm{SD}=3.56, \min =30, \max =47)$ and the mean years of education was 15.20 years $(\mathrm{SD}=1.88, \min =12, \max =18)$. Among the participants, six were high school graduates, 17 were university graduates, and two were graduate school graduates. They were all resi- 
dents of Daejeon in the Republic of Korea and spoke Korean as their mother tongue.

As shown in Table 1, the children of the participants consisted of 21 males and four females. The mean age of the children was 9.40 years old $(\mathrm{SD}=3.98, \min =3, \max =18)$. Five were in preschool, 15 in elementary school, two in middle school, and three in high school. The children had autism spectrum disorder $(n=18,72 \%)$, intellectual disability $(n=5,20 \%)$, and brain lesion disorder $(n=2$, $8 \%)$. The main communication mode for expression was gestures $(n=11,44 \%)$, followed by speaking $(n=7,28 \%)$, vocalization $(n=5$, $20 \%)$, and facial expressions ( $n=2,8 \%) .16$ participants $(64 \%$ of the total) reported that the intelligibility of their children's speech was too low for comprehension. Seven of 16 participants stated that

Table 1. Demographic characteristics of children of the research participants

\begin{tabular}{llrc}
\hline Category & \multicolumn{1}{c}{ Subcategory } & N & Percent (\%) \\
\hline Sex & Male & 21 & 84.0 \\
& Female & 4 & 16.0 \\
Type of disability & Autism spectrum disorder & 18 & 72.0 \\
& Intellectual disability & 5 & 20.0 \\
& Brain lesion disorder & 2 & 8.0 \\
Education level & Preschool & 5 & 20.0 \\
& Elementary school & 15 & 60.0 \\
& Middle school & 2 & 8.0 \\
& High school & 3 & 12.0 \\
Primarily communication & Spoken & 7 & 28.0 \\
Mode for expression & Vocalization & 5 & 20.0 \\
& Facial expression & 2 & 8.0 \\
& Gesture & 11 & 44.0 \\
\hline
\end{tabular}

Table 2. Contents of parent education program on AAC

\begin{tabular}{|c|c|c|}
\hline \# & Category & Contents \\
\hline \multirow[t]{3}{*}{1} & Introduction to AAC & 1-1. What is AAC? \\
\hline & & 1-2. Who can benefit from AAC? \\
\hline & & 1-3. Myths and realities \\
\hline \multirow[t]{2}{*}{2} & Exploring AAC systems & 2-1. Various types of AAC systems \\
\hline & & 2-2. Mid- and high-tech AAC systems available in Korea \\
\hline \multirow[t]{2}{*}{3} & Developing linguistic competence using & 3-1. Communicative levels of children who require $A A C$ \\
\hline & $\mathrm{AAC}$ & 3-2. Understanding the core and fringe vocabulary \\
\hline \multirow[t]{3}{*}{4} & Tips for using AAC at home & 4-1. Increasing interaction with children who rely on AAC \\
\hline & & 4-2. Using visual schedule at home \\
\hline & & 4-3. Using the communication board to participate in daily activities \\
\hline \multirow[t]{3}{*}{5} & Policies and financial support & 5-1. Financial support for the purchase of AAC devices by the Korean Agency for Digital Opportunity and Promotion \\
\hline & & 5-2. Device rental support by Assistive Technology Centers \\
\hline & & 5-3. Financial support for AAC intervention services by the Ministry of Health and Welfare \\
\hline
\end{tabular}

they could not understand a single word of their children's speech. The rest of the participants $(n=9)$ reported that they had no difficulty or only slight difficulty understanding what their children said but that their expressive language skills and the number of words that they can express were limited. The seven children surveyed who communicated verbally were found to have very low speech intelligibility for comprehension, or a very limited number of single-word utterances. Regarding children's receptive language skills, two children did not understand at all, nine children showed word level comprehension, and 14 simple phrase/sentence level comprehension. The mean years of the speech-language therapy that the children received was 6.22 years $(\mathrm{SD}=3.13, \min =1.5$, $\max =14)$.

\section{Education Program and Material}

The education program was designed as one visit and was developed by reviewing published literature on AAC (e.g., Beukelman \& Mirenda, 2013; Ganz, 2014; Light, Beukelman, \& Reichle, 2003). In addition, policy and funding information was included to financially support the parents who would need the AAC services. As shown in Table 2, the program consisted of five sections: (1) Introduction to AAC, (2) Exploring AAC systems, (3) Developing linguistic competence using AAC, (4) Tips for using AAC at home, and (5) Policies and financial support. These sessions were conducted in numerical order. A booklet covering all the sections was developed (see Appendix 1). The booklet consisted of a total of 10 pages excluding the table of content and all sessions were equal- 
ly composed of two pages. The education program and the booklet were reviewed by a professor who received their doctorate in the field of AAC.

Participants were provided with the opportunity to try several AAC systems to expand their awareness of AAC options for their children's communication during the second section, that is exploring AAC systems. Two mid-tech devices available in Korea (Go Talk 20 plus [Attainment Company, n.d.]; OK Talk Talk (Version 1.0.5) [Geni Cube, 2016]) and two high-tech AAC applications (My Talkie Smart [Voiceware, 2018]; My AAC - for general use [NC Foundation, 2017]) were tried during the parent education. Following the researchers' modeling, participants used the devices to select symbols and form simple sentences.

\section{Development of Survey Questionnaires}

First, to measure the effect of parent education on parents' AAC perception, survey questionnaires consisting of 8 items were developed based on literature that discusses misconceptions about AAC (Bailey et al., 2006; Cress \& Marvin, 2003; Romski \& Sevcik, 2005; Smith, Barton-Hulsey, \& Nwosu, 2016; Starble, Hutchins, Favro, Prelock, \& Bitner, 2005). Surveys were conducted with the same questionnaires before and after providing parent education. Participants were asked to respond to each item regarding an AAC misconception using the 5-point Likert scale ( $1=$ strongly agree, $2=$ agree, $3=$ neutral, $4=$ disagree, and $5=$ strongly disagree).

Next, another set of survey questionnaires was developed to examine the relationship of participants' change in perception of AAC with their satisfaction with the parent education, also on the 5 -point Likert scale. It consisted of 8 items on a variety of aspects of the program (e.g., overall satisfaction with the education program, appropriateness of the amount of time it took, ease of understanding, and helpfulness with AAC devices).

The content validities for the two survey questionnaires were obtained by two raters who are professors in the Department of Speech \& Language Pathology and have more than 10 years of education, research, and clinical experience in the AAC field.

\section{Procedure}

Given that in the clinical settings, clinicians often provide information about AAC to individual parents and answer questions re- lated to their children, parent education was provided to each participant by a single researcher, mainly from the speech therapy center at the University. If necessary, the researcher visited the participant's home or any private and quiet place such as a room at a special education school or a local facility for people with disabilities.

After obtaining signed consent forms from the participants, a pre-survey on parent perceptions was conducted before the parent education. Parent education was designed with 40 minutes of content. Including the question-and-answer time, sessions lasted for 1 to 1.5 hours. The length of sessions did not exceed 1.5 hours in consideration of the concentration and fatigue of the participants. After the parent education, each participant completed a post-survey on AAC perception followed by the survey on satisfaction with the program. The researcher left the room after verbally communicating to the participants the need for an objective evaluation, and the participants completed both surveys in the absence of the researcher.

The researcher who provided the education was a graduate student in speech-language pathology. The researcher spent six months developing the parent education program and preparing answers to potential questions related to the communication challenges and AAC approaches of the research participants. This preparation phase was completed so that the researcher could provide correct, reliable, and helpful information to parents, and this phase was reviewed and monitored by the professor whose primary research and clinical area is AAC.

\section{Data Analysis}

To determine whether there was a significant difference between the pre- and the post-surveys on AAC perception, a paired $t$-test was performed for each survey item. Also, a repeated measures ANCOVA was conducted on the total pre-survey scores and the total post-survey scores to examine whether other child-relevant variables such as age duration of speech therapy would impact on parents' perceptions.

To identify any significant correlation between the satisfaction with the program and the change in AAC perception, a Spearman correlation coefficient analysis was performed. To run the analysis, the total satisfaction scores were computed by summing the 8 survey items' scores for each participant. Change in AAC percep- 
tion was computed by subtracting the total pre-survey scores from the total post-survey scores for each participant. IBM SPSS Statistics version 26 was used for statistical analyses.

\section{RESULTS}

\section{Changes in AAC Perception Following the Provision of Parent Education}

The mean AAC perception scores obtained by the sum of presurvey scores and the sum of post-survey scores for 25 participants divided by 25 were $26.48(\mathrm{SD}=4.08)$ and $32.68(\mathrm{SD}=4.27)$, respectively. The mean scores for all survey items increased at post-survey and the differences between pre- and post-survey scores were all significant except for the survey item "Children's use of AAC places an additional burden on parents" (Table 3). The biggest change was observed in the survey items "Children must have normal cognitive skills to use speech-generating devices" (mean difference $=1.20$ ) and "Only children of a certain age can benefit from AAC" (1.20). The former item was the one which showed the lowest mean scores at the pre-survey. The item with the next highest difference was "AAC is only applicable for children who cannot speak" (.92), followed by "AAC is considered as a last resort in speech-language intervention" (.88) and "It is difficult to apply AAC in natural everyday situations outside the treatment room" (.68).

In addition, the repeated measured ANCOVA showed that the difference between the total scores of pre-and post-surveys was significant $(\mathrm{F}=17.164, p<.001)$. Age of children and duration of speech-language therapy had no effect on the perception change as covariates.

\section{Correlation with Satisfaction of Parent Education Program}

Participants showed relatively high satisfaction with the parent education (Table 4). The highest mean score was $4.84(\mathrm{SD}=.37)$ for the survey item "Exploring devices helped me understand AAC" followed by "The education was delivered in an easy-to-understand way" ( $\mathrm{M}=4.80, \mathrm{SD}=.41)$, "The one-on-one education was helpful" ( $\mathrm{M}=4.76, \mathrm{SD}=.44)$, "Overall, I am satisfied with this education" $(\mathrm{M}=4.76, \mathrm{SD}=.44)$, "The education time was adequate" $(\mathrm{M}=4.64, \mathrm{SD}=.49)$, "I'd like to recommend this program to other parents" $(\mathrm{M}=4.56, \mathrm{SD}=.58)$, "I am willing to attend another $\mathrm{AAC}$ education program" $(\mathrm{M}=4.52, \mathrm{SD}=.65)$, and "This education motivated me to try AAC systems for my children" $(\mathrm{M}=4.52, \mathrm{SD}=.59)$.

The Spearman's rho was $.443(p=.027)$, indicating a moderate

Table 4. Results of satisfaction survey

\begin{tabular}{llccc}
\hline$\#$ & \multicolumn{1}{c}{ Items } & N & Mean & SD \\
\hline 1 & Overall, I am satisfied with this education. & 25 & 4.76 & .44 \\
2 & The education time was adequate. & 25 & 4.64 & .49 \\
3 & The one-on-one education was helpful. & 25 & 4.76 & .44 \\
4 & The education was delivered in an easy-to-understand way. & 25 & 4.80 & .41 \\
5 & Exploring devices helped me understand AAC. & 25 & 4.84 & .37 \\
6 & I am willing to attend another AAC education program & 25 & 4.52 & .65 \\
7 & I'd like to recommend this program to other parents. & 25 & 4.56 & .58 \\
8 & This education motivated me to try AAC systems for my & 25 & 4.52 & .59 \\
& children & & & \\
\hline
\end{tabular}

$\mathrm{N}=$ Number of people who responded to the questionnaire.

Table 3. Mean scores of pre- and post-surveys obtained from 25 participants

\begin{tabular}{|c|c|c|c|c|c|c|}
\hline$\#$ & Survey items & Pre-survey (A) & Post-survey (B) & $(B)-(A)$ & $t$ & $p$ \\
\hline 1 & AAC is considered as a last resort in speech-language intervention. & $2.92(1.12)$ & $3.80(1.32)$ & .88 & $-3.561^{* *}$ & .002 \\
\hline 2 & AAC is only applicable to children who cannot speak. & $3.16(1.07)$ & $4.08(1.19)$ & .92 & $-3.663^{* *}$ & .001 \\
\hline 3 & Children must have normal cognitive skills to use speech-generating devices. & $2.60(.87)$ & $3.80(108)$ & 1.20 & $-5.367^{* * *}$ & .000 \\
\hline 4 & Only children of a certain age can benefit from AAC. & $3.28(1.06)$ & $4.48(.71)$ & 1.20 & $-6.573^{* * *}$ & .000 \\
\hline 5 & AAC delays or hinders speech development. & $3.76(.88)$ & $4.40(.50)$ & .64 & $-4.571^{* * *}$ & .000 \\
\hline 6 & Children's use of AAC places an additional burden on parents. & $3.56(1.12)$ & $3.72(1.21)$ & .16 & -0.941 & .356 \\
\hline 7 & It is difficult to apply AAC in natural everyday situations outside the treatment room. & $3.52(.96)$ & $4.20(.82)$ & .68 & $-3.302^{* *}$ & .003 \\
\hline 8 & $\begin{array}{l}\text { The success of AAC depends entirely on the role of experts such as speech-language } \\
\text { pathologists and special teachers. }\end{array}$ & $3.68(.90)$ & $4.20(.58)$ & .52 & $-2.701^{*}$ & .012 \\
\hline
\end{tabular}

Values are presented as mean (SD).

${ }^{*} p<.05,{ }^{* *} p<.01,{ }^{* * *} p<.001$. 
positive correlation between the degree of satisfaction and the change in AAC perception.

\section{DISCUSSION \& CONCLUSION}

The importance of parent education regarding AAC has been emphasized in previous studies (e.g., Anderson, 2015; Parette Jr et al., 2000; Thunberg et al., 2009) but without empirical evidence of its impact on AAC perception. This study showed that parent education focused on correcting misconceptions about AAC and providing relevant information had a positive effect on parents' perceptions of AAC. These results are consistent with previous studies that AAC family support leads to changes in parents' perceptions and attitudes (Kim \& Park, 2003; Kim \& Park, 2012) and that parent education is effective in raising awareness of the use of AAC (Bruno \& Dribbon, 1998; Fanale, 2013). As studies have raised the need for family support and parent education (Anderson et al., 2015; Angelo et al., 1995; Lim et al., 2013; Park, 2020; Shin \& Lee; 2016), and this study came to the conclusion that the parent education has a positive effect on improving their AAC awareness, it is necessary to develop a plan for the continuous development and spread of parent education programs.

Interestingly, the mothers who participated in this study were found to be somewhat at odds with the idea that AAC impedes their children's speech development even before they were educated. This is quite different from the results of previous studies that AAC causes children to give up speech production and negatively affects speech therapy (Oh, 2018; Shin \& Lee, 2016). This difference may be due to the demographic characteristics of the parents who participated in each study. Also, there is a possibility that the previous exposure to AAC education and/or training might affect the parents' perception. Therefore, we cannot generalize this finding to parents in other cities or countries, as they may show different responses for each misconception depending on their existing levels of knowledge and experience with AAC.

Looking at the characteristics of the participants who had a relatively strongly negative perception of AAC, it was found that mothers had no prior information and experience with AAC, their children were older than middle school, or their children had more than 7 years of speech therapy experience. It seems that the bur- den and concern about a new communication system formed a negative perception of AAC (Goldbart \& Marshall, 2004; Jones et al., 1999). It also shows that accurate information about AAC was not communicated to parents while receiving speech therapy for a long time. This demonstrates the importance of parent education.

The change of perception due to parent education highlights the role of SLPs in building parents' motivation to participate in their child's intervention phases (Baxter et al., 2012; Moorcroft et al., 2019). This study did not show explicitly whether Korean parents whose perception of AAC demonstrated improvement would actually adopt an AAC system to help their children communicate. However, the result of the satisfaction survey indirectly indicates a potential increased likelihood of adopting the AAC system. That is, mothers rated the survey item "This education motivated me to try AAC system for my children” highly $(\mathrm{M}=4.52$, which is between "agree" and "strongly agree").

Correlation of satisfaction with perception of AAC was found to be moderate. It seems that this is because the Korean parents gave high scores in general. Nevertheless, the significant correlation indicates that the parent education's delivery of AAC information and the opportunity for familiarization with the devices is a welcome way for parents to raise their awareness. In cases where the parent lacks experience with AAC devices and this lack impacts their understanding of AAC, we recommend including a device trial session in the program. One-on-one education is also recommended if parents wish to receive more specific information related to their children. Previous studies have also discussed the effectiveness of one-to-one consultation and device experience opportunities (McNaughton et al., 2008; Parette Jr et al., 2000; Starble et al., 2005).

It should be noted that this study measured only the short-term effect of parent education on AAC perception without any comparison group. Further study will be needed to confirm whether changes in parents' perceptions and attitudes can play a role in their engagement in AAC intervention phases, as opposed to parents who have not been educated as here described. Another limitation of this study is that, as already mentioned, the cultural characteristics of Korea may have influenced the study results. For example, the fact that the recruited participants were all mothers and that it is not easy for them to access information on AAC devices 
and policies in Korea in particular may lead to different results from studies done in other countries. Therefore, when conducting parent education, it is recommended to modify the contents and composition of the education used in this study according to the actual situation of the country and the target parents. Lastly, this study devised a parent education program that can be directly applied to the parents of children with various disabilities in the field. Therefore, the type of individual children's disabilities and their ages were not controlled when recruiting the research participants. However, if an education program is developed according to the individual type of disability and age, it is expected to be of greater help to parents.

\section{REFERENCES}

Anderson, K. L. M. (2015). Supporting the families of children with a new speech generating device (SGD): a mixed-methods investigation. International Journal of Speech-Language Pathology, 17(2), 185-95.

Angelo, D., Jones, S., \& Kokoska, S. (1995). Family perspective on augmentative and alternative communication: families of young children. Augmentative and Alternative Communication, 11(3), 193-202.

Attainment Company. (n.d.). Go Talk 20 plus. Retrieved from https://www. attainmentcompany.com/mwdownloads/download/link/id/1162/.

Bailey, R. L., Parette Jr, H. P., Stoner, J. B., Angell, M. E., \& Carroll, K. (2006). Family members' perceptions of augmentative and alternative communication device use. Language, Speech, and Hearing Services in Schools, 37(1), 50-60.

Baxter, S., Enderby, P., Evans, P., \& Judge, S. (2012). Barriers and facilitators to the use of high-technology augmentative and alternative communication devices: a systematic review and qualitative synthesis. International Journal of Language and Communication Disorders, 47(2), 115-129.

Beukelman, D. R., \& Mirenda, P. (2013). Augmentative and alternative communication: supporting children and adults with complex communication needs (4th ed.). Baltimore, MD: Paul H. Brookes Publishing Co.

Bruno, J., \& Dribbon, M. (1998). Outcomes in AAC: evaluating the effectiveness of a parent training program. Augmentative and Alternative Communication, 14(2), 59-70.

Cress, C. J., \& Marvin, C. A. (2003). Common questions about AAC services in early intervention. Augmentative and Alternative Communication, 19(4), 254-272.
Fanale, S. (2013). The effects of an AAC communication partner training program (Master's Thesis), Eastern Illinois University, Illinois, USA.

Ganz, J. B. (2015). AAC interventions for individuals with autism spectrum disorders: state of the science and future research directions. Augmentative and Alternative Communication, 31(3), 203-214.

Geni Cube. (2016). OK Talk Talk (Version 1.0.5) Retrieved from http://edufriend.co.kr/shop/goods/goods_view.php?goodsno=50\&category=003.

Goldbart, J., \& Marshall, J. (2004). "Pushes and pulls" on the parents of children who use AAC. Augmentative and Alternative Communication, 20(4), 194-208.

Granlund, M., BjÖrck-ÅKesson, E., Wilder, J., \& Ylvén, R. (2008). AAC interventions for children in a family environment: implementing evidence in practice. Augmentative and Alternative Communication, 24(3), 207-219.

Huer, M. B., \& Lloyd, L. (1990). AAC users perspectives on augmentative and alternative communication. Augmentative and Alternative Communication, 6(4), 242-249.

Johnson, J. M., Inglebret, E., Jones, C., \& Ray, J. (2006). Perspectives of speech language pathologists regarding success versus abandonment of AAC. Augmentative and Alternative Communication, 22(2), 85-99.

Jones, S. D., Angelo, D. H., \& Kokoska, S. M. (1999). Stressors and family supports: families with children using augmentative \& alternative communication technology. Journal of Children's Communication Development, 20(2), 37-44.

Kent-Walsh, J., Binger, C., \& Hasham, Z. (2010). Effects of parent instruction on the symbolic communication of children using augmentative and alternative communication during storybook reading. American Journal of Speech-Language Pathology, 19(2), 97-107.

Kim, K. Y., \& Park, E. H. (2012). The effect of the family-centered AAC intervention for a child with autism spectrum disorder and his family. Journal of the Korean Association for Persons with Autism, 12(1), 51-72.

Kim, J. Y., \& Park, E. H. (2003). AAC communicative partner training to enhance communication skills of children with severe cerebral palsy. Special Education Research, 2(1), 37-58.

Light, J. C., Beukelman, D. R., \& Reichle, J. (Eds.). (2003). Communicative competence for individuals who use augmentative and alternative communication. Baltimore, Maryland: Paul H. Brooks Publishing Co.

Lim, J., Park, E. H., \& Ku, J. (2013). A study on experiences and needs of potential AAC users' parents regarding AAC intervention services. Special Education Research, 12(3), 309-332.

Marshall, J., \& Goldbart, J. (2008). 'Communication is everything I think': 
parenting a child who needs augmentative and alternative communication (AAC). International Journal of Language \& Communication Disorders, 43(1), 77-98.

McNaughton, D., Rackensperger, T., Benedek-Wood, E., Krezman, C., Williams, M. B., \& Light, J. (2008). "A child needs to be given a chance to succeed": parents of individuals who use AAC describe the benefits and challenges of learning AAC technologies. Augmentative and Alternative Communication, 24(1), 43-55.

Moorcroft, A., Scarinci, N., \& Meyer, C. (2019). Speech pathologist perspectives on the acceptance versus rejection or abandonment of AAC systems for children with complex communication needs. Augmentative and Alternative Communication, 35(3), 193-204.

NC Foundation. (2017). My AAC (Version 1.0.2) [Mobile app]. Retrieved from https://play.google.com/store/apps/details?id=kr.or.nc foundation.myaackids.

Oh, H. J. (2018). A case study on parents' awareness and support request for the application of augmentative and alternative communication (AAC) for their children with disability. The Korean Society of Education for Hearing-Language Impairments, 9(2), 175-196.

Parette Jr, H. P., Brotherson, M. J., \& Huer, M. B. (2000). Giving families a voice in augmentative and alternative communication decision-making. Education and Training in Mental Retardation and Developmental Disabilities, 35(2), 177-190.

Park, H. (2020). Parents' experiences and acceptance factors of AAC intervention for children with complex communication needs. Communication Sciences \& Disorders, 25(2), 318-333.
Park, H. (2021). "I kept questioning it in the first 6th months": the process of AAC acceptance in parents of children with complex communication needs. Communication Sciences \& Disorders, 26(1), 120-136.

Park, H. B., Lee, J. Y., \& Park, H. (2020). Experences and demands in parents of children with complex communication needs on AAC abandonment. AAC Research \& Practice, 8(2), 51-75.

Romski, M., \& Sevcik, R. A. (2005). Augmentative communication and early intervention: myths and realities. Infants « Young Children, 18(3), 174-185.

Seligman-Wine, J. (2007). Supporting families of children who use AAC. The ASHA Leader, 12(10), 17-19.

Shin, J. M., \& Lee, S. (2016). Parent's perception on augmentative and alternative communication for students with severe disability. AAC Research \& Practice, 4(2), 1-18.

Smith, A. L., Barton-Hulsey, A., \& Nwosu, N. (2016). AAC and families: dispelling myths and empowering parents. Perspectives of the ASHA Special Interest Groups, 1(12), 10-20.

Starble, A., Hutchins, T., Favro, M. A., Prelock, P., \& Bitner, B. (2005). Familycentered intervention and satisfaction with AAC device training. Communication Disorders Quarterly, 27(1), 47-54.

Thunberg, G., Sandberg, A. D., \& Ahlsén, E. (2009). Speech-generating devices used at home by children with autism spectrum disorders: a preliminary assessment. Focus on Autism and Other Developmental Disabilities, 24(2), 104-114.

Voiceware. (2018). My Talkie Smart [Computer software]. Retrieved from http://www.mytalkie.co.kr/product/product03.php. 
Appendix 1. Part of a booklet used for parent education about AAC

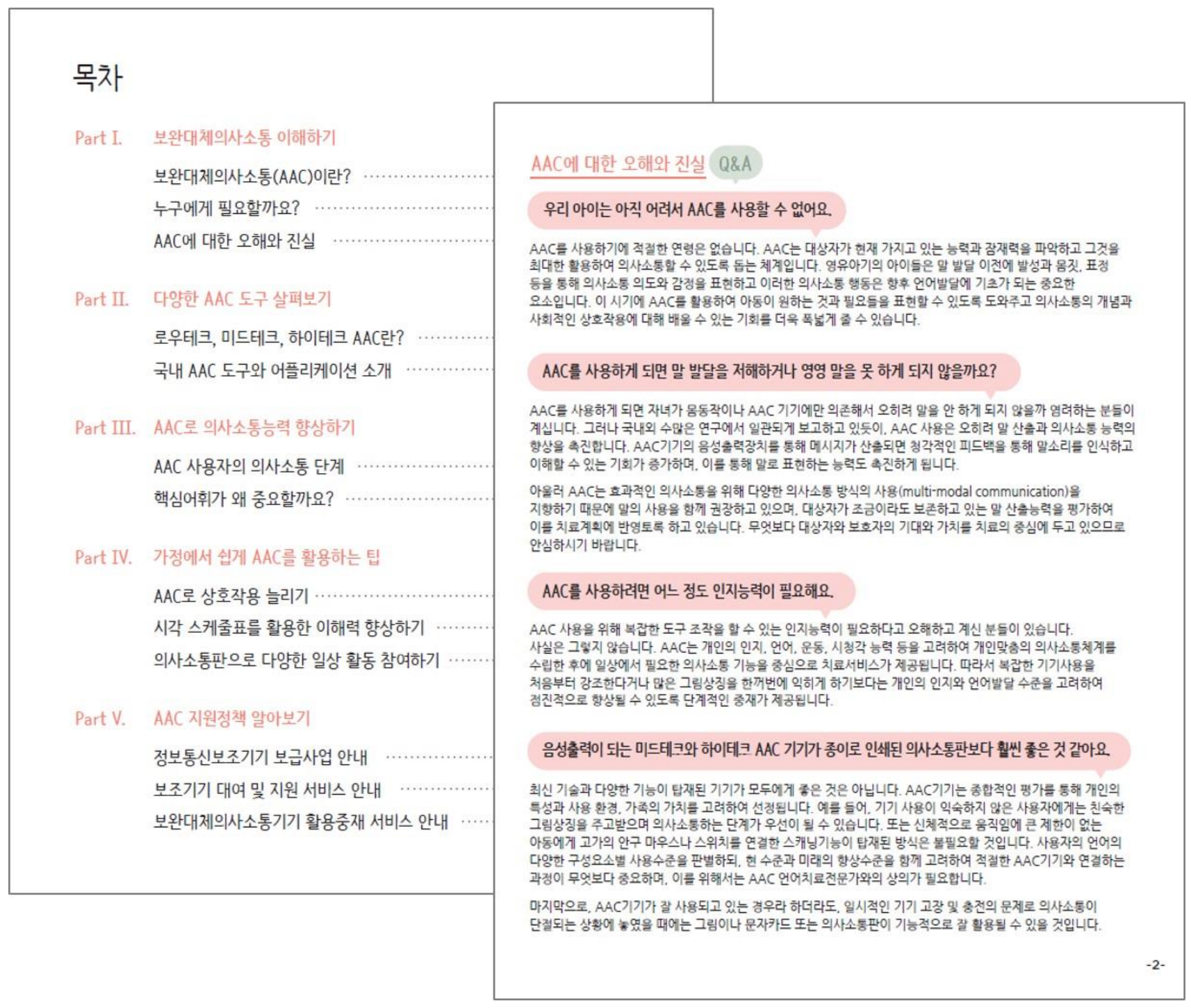




\section{Part II. 다양한 AAC 도구 살펴보기}

\section{로우테크, 미드테크, 하이테크 AAC란?}

우리가 일상에서 의사소통을 할 때 말뿐 아니라 제스쳐, 표정, 그림이나 사진. 글 등의 다양한 방병 사용하는 것처럼 AAC 사용자들도 다양한 형태의 의사소통 방식을 상황에 맞게 사용합니다.

이러한 의사소통 방식들은 각각의 특징에 따라 비도구적 $\mathrm{AAC}$ 와 도구적 $\mathrm{AAC}$ 로 나뉩니다. 비도구적 AAC는 발성. 몸짓, 수화. 표정과 같이 사용자의 신체를 사용하는 것을 말하며 도구적 AAC는 도구를 사용하는 방식으로 기능과 특징에 따라 Low-tech, Mid-tech, High-tech로 세분화 됩니다.

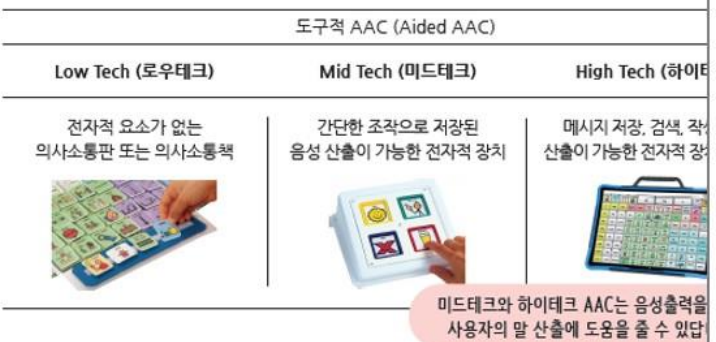

\section{국내 $\mathrm{AAC}$ 도구와 어플리케이션 소개}

- 국내 제조사가 개발한 미드테크와 하이테크 AAC 도구의 예 -

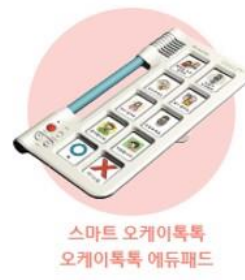

- 녹음출력 기기와 태블릿 버전 제공 -2 개의 모드 6 개 채널 지원으로 120 개의 어휘 제공 - 자체 녹음기능 제공 및 녹음된 메시지 산출 가능 - SW를 통한 컴퓨터 연동 자료 (그림 및 음성) 활용 가

-600 개의 어휘 제공

- 사용자에 따라 화면크기 $1 * 1$ 에서 $7 \approx 4$ 설정 가능

- 사용자에 맞게 상징 배치 및 편집 가능

- 남성/여성 목소리로 음성 출력 가능
$-3-$

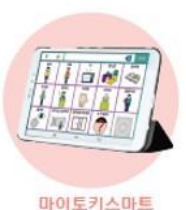

-10.000 개 이상의 어휘 제공 - 사용자에 맞게 상징 배치 및 편집 가능

- 사용 환경에 맞게 구성된 수준별 판 제공

-TIS 기반의 음성합성 및 산출 가능

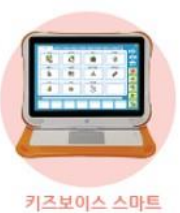

-3.200 개의 어휘 제공

- 사용자에 맞게 상징 배치 및 편집 가능

- 의미범주별로 저장된 그림상징 기반의 인터페이스 제공

-TIS 기반의 음성합성 및 산출 가능

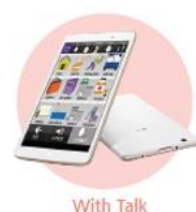

-3.000 개 이상의 어휘 제공

- 사용자에 맞게 상징 배치 및 편집 가능

- 키보드 사용 및 터치가 어려운 사용자를 위한

키보드 스캐닝 기능 제공

TIS 기반의 옴성합성 및 산출 가능

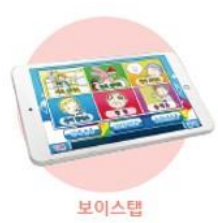

언어훈련 프로그램과 그림상징 기반의

의사소통판 제공

- 게임을 통한 언어훈련 및 인지 학습 가능

- TIS 기반의 음성합성 및 산출 가능

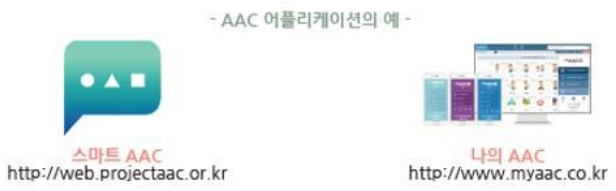

모바일, 태블릿 버전 활용가능

사용자의 능력에 따른 그림영 운자형 앱 선택 가능

- 개인별 어플리케이션 사용 현황 분석 제공

- 서버 연동으로 백업 기능 지원

- 고빈도 기본 상징 및 최근 사용한 상징 확인 기능 제공

모바일, 태블릿, $\mathrm{PC}$ 버전 가능

모바일의 경우 장소/의미 범주별 상징 구분 기능 제공

- 사용자에 따라 기초, 아동. 일반 앱 선택가능

이야기 만들어 전달하기 기능 제공

- TS 기반의 음성합성 및 산출 가능 


\section{핵심어휘가 왜 중요할까요?}

기술의 발달로 수많은 어휘를 AAC기기에 저장할 수는 있으나. 자주 사용하지 않는 어휘를 접근성 높은 위치에 배치하게 되면 일상에서 정작 필요혀 활용빈도가 낮아지게 될 것이며 의사소통의 단절은 극복되기 힘들 것입니다.

\section{Part IV. 가정에서 쉽게 $\mathrm{AAC}$ 를 활용하는 팁}

따라서 AAC를 통한 효과적인 의사소통을 위해서는 사용자의 연령. 언어발달수준. 현재와 미래의 의사소통 필요, 의사소통 환경 등을 고려하여 적절한 어휘를 선정하쉽게 접근할 수 있도록 배치하는 것이 매우 중요합니다.

이를 위해 국내외 AAC 연구자들은 핵심어휘를 파악하는 것에 많은 노력을 기울여

핵심어휘란 일상에서 자주 사용되는 고빈도의 단어로,

대화주제나 대화상황에 크게 영향 받지 않으며,

개인뿐만 아니라 다른 사람들도 공통적으로 많이 사용하는 0

예시 '주세요', ‘더', '나', '많이’, ‘조금', ‘해요', 빨리’ 등

부수어휘란 개인의 개별 의사소통 상황에 따라 사용되는 어휘로, 핵심어휘에 비해 사용되는 빈도가 낮으며, 다양한 의사소통 사용되지는 않는 어휘를 말합니다.

예시 병원놀이 상황에서의 ‘청진기', 은행 업무를 볼 때 필요한 '통장.

교회에서만 만나는 지인의 이름 등

$\mathrm{AAC}$ 언어치료전문가와 함께 중재계획을 세울 때에는 사용자의 핵심어휘를 파악하 접근성 높은 곳에 배치하고. 그 외의 핵심어휘 및 부수어휘에 대해서는 구문적-의미 고려하여 개인맞춤의 의사소통판을 제작하게 됩니다.

이러한 어휘선정 과정에는 언어재활사뿐만 아니라 사용자 그리고 사용자의 의사소 잘 알고 있는 가족, 선생님, 친구, 직장동료 등이 중요한 정보제공자가 될 수 있습니

\section{$\mathrm{AAC}$ 로 상호작용 늘리기}

가장 오랜 시간을 보내는 가정 그리고 가장 친숙한 대상인 부모 및 가족이 $\mathrm{AAC}$ 촬용에 참여하는 것은 아동 및 성인의 의사소통능력에 긍정적인 결과를 가져올 수 있습니다.

가정에서 적용할 수 있는 몄 가지 방법들을 알아보아요!

1 첫째, 의사소통 시도를 위한 기회를 만들어 주세요!

우유와 요구르트 사진을 놓고 원하는 간식을 직접 선택할 수 있게 해주세요. 줗아하는 장난감이나 물건을 손이 당지 않는 선반 위에 올려두거나. 식사 시간에 밥만 주고 숟가락은 주지 않는 상황을 만들어 직접 요구할 수 있도록 해주세요.

2 둘째, 질문을 하여 반응을 이끌어 주세요

"무슨 놀이를 할까?", "뭐 하고 있어?"와 같이 직접적인 질문으로 관심과 반응을 이끌어 주세요. $\mathrm{AAC}$ 를 사용하여 문장으로 대답하기 어려운 경우에는 질문의 난이도를 낝춰서 '네/아니오'로 대답할 수 있는 간단한 질문을 해주세요.

3 셋째, 반응을 기다려주세요!

질문을 한 뒤에는 $\mathrm{AAC}$ 를 사용하여 반응할 수 있도록 약 5 초 정도 기대하는 표정으로 기다려 주세요 대답을 위해 AAC 사용을 시도 중이라면 시간이 더 걸리더라도 스스로 할 수 있도록 기다려 주세요.

만약 반응을 보이지 않으면 언어적인 단서를 주거나 ('줗아요'라고 말해볼까요?) 사용자의 의사소통판에서 해당되는 상징주변을 가리켜 주거나, 직접 사용자의 손을 잡고 상징을 선택할 수 있게 도와주세요. 단서를 주었을 때 어느 정도 안정적으로 반응을 한다면. 이제는 독립적인 의사소통자가 될 수 있도록 단서의 제공 횟수를 점차 줄여주세요.

4 넷째, 시범을 보여주세요

일상에서 자연스럽게 상호작용 하면서, AAC 상징판을 함께 활용해 주세요. 가령 아동과의 놀이 상황에서 의사소통판에 있는 '아기' 와 '우유' 그림상징을 선택하는 모습을 보여주세요

"아기 우유"가 음성 산출되면, 아기인형에게 우유를 먹이는 동작으로 강화를 주세요. 자녀가 그 모습을 보고 그대로 따라할 때마다 말로 또는 관련된 동작으로 강화를 주세요.

$\mathrm{AAC}$ 를 사용하는 성인이 자신의 물건을 잃어버리고 도움을 청하고 있지 않다면. 그 상황에서 $\mathrm{AAC}$ 의 글자판을 사용하여 어떻게 도와달라고 해야 하는지 시범을 보여주시고 스스로 다양한 상황에서 활용할 수 있도록 도움을 주세요. 


\section{시각스케줄 활용하기}

하루 동안 참여하는 활동을 그림상징으로 만들어 주세요.

시각스케줄 표는 순차적인 활동 간의 순서를 파악하고. 현재 해야 할 일에 집중하게 해주며. 앞으로 일어날 일을 예측할 수 있도록 도와줍니다.

아동과 성인의 청각적인 이해능력이 낮은 경우 말로만 행동을 지시하는 것을 이해하기가 쉽

있습니다. 이럴 경우 시각적으로 그림이 제공되는 시각스케줄을 통해 이해력을 증진할 수 이

가정 내 다양한 일상생활에서 스스로 해결할 수 있는 범위를 넓혀주게 됩니다.

예시 학교 가기 전까지 해야 할 일

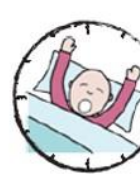

일어나기

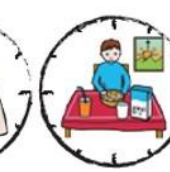

밥먹기

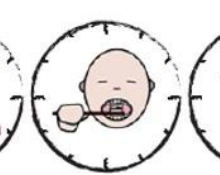

양치질하기

\section{의사소통판으로 다양한 일상 활동 참여하기}

아동 또는 성인의 의사소통판을 사용하여 다양한 활동에 참여할 수 있는 기회를 만들어주세 치료실에서 익힌 핵심어휘와 부수어휘를 사용하여 치료실 밖에서도 자발적으로 적절한 상횡 사용할 수 있도록 하기 위해서는 가정의 역할이 중요합니다.

예시 놀이 상황
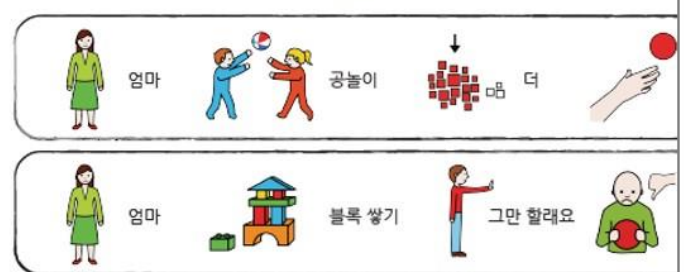

The pictograms used are the property of Aragon Government and have been created by Sergio Palao to distribute them under Creative Commons License (BY-NC-SA). The non-profit organization 'With A.
tive' in S. Korea obtained permission to use it from the ARASAAC Coordinators on June 5 th. 2019 .

\section{Part V. AAC 지원정책 알아보기}

\section{정보통신보조기기 보급사업 안내}

한국정보화진홍원과 각 지방자치단체에서는 신체적·경제적으로 정보통신에 대한 접근과 활용이 어려운 장애인을 대상으로 정보화를 통한 사회 통합을 유도하고 정보격차를 해소하기 위해 정보통신보조기기를 지원하고 있습니다.

사업내용

- 보 급 대 상 장애인복지법에 의해 등록한 장애인 및 국가유공자 등
예우 및 지원에 관한 법에 의해 상이등급 판정을 받은 자

- 지 원 내 역 보조기기 제품 가격의 일정 금액 지원
*기초생활수급자. 차상위계층 등 경제적 여건이 어려운

저소득 장애인의 경우 본인부담금에 대한 추가 지원

- 보 급 풍 목 시각. 청각/언어, 지체/뇌병변 등 장애유형에 적합한 정보통신보조기기 및 특수 SNW

* *보급제품은 매년 보급품목선정위원회에서 선정

- 보조기기전시·체험 정보통신보조기기 체험전시관 운영

정보통신보조기기 전시회 개최

- 활용 후 사후관리 보조기기 사용자 교육(필요시 관련업체에서 실시)

수혜자 만족도 및 이용실태조사

보조기기 무상수리 (무상수리기간 1년)

춧 무상수리기간 이후는 납품업체의 A/S 관련 규정을 준용

신청절차

\begin{tabular}{|c|c|c|c|c|c|c|c|c|}
\hline 01 & 02 & 03 & 04 & 05 & $>06$ & 07 & 08 & 09 \\
\hline 전화 & 신청 & 방문 & 대상자 & 결과 & 개인부담금 & 기기배송 & 수령확인서| & 보급 \\
\hline 상담 & 접수 & 상담 & 선정 & 발표 & 납부 & 설치 & 이용약관 & 완료 \\
\hline $1588-2670$ & (지자체) & (지자쳐) & (지자체) & (지자쳬) & & (납품업체) & 제술 & \\
\hline
\end{tabular}

* 한국정보화진흥원의 정보통신보조기기 홍페이지 www.at4u.or.kr 를 통해

자세한 내용을 확인하실 수 있으며 예산 및 정책에 따라 지원 내용은 변경될 수 있습니다. 


\section{국문초록}

\section{부모 교육이 보완대체의사소통 인식에 미치는 영향}

김상민 ${ }^{1} \cdot$ 박현주 $^{2}$ · 신상은

충남대학교 대학원 언어병리학과, ${ }^{2}$ 가천대학교 특수치료학과

배경 및 목적: $\mathrm{AAC}$ 에 대한 부모의 부족한 지식은 오해와 편견을 야기할 수 있으며 이는 자녀에게 적절한 중재를 제공하는 데 있어 방 해 요인으로 작용할 수 있다. 이에 본 연구는 부모 교육이 AAC에 대한 인식 변화에 영향을 미치는지를 살펴보고자 하였다. 방법: 복합 적인 의사소통 요구를 지닌 아동을 둔 25 명의 어머니가 본 연구에 참여하였다. 부모 교육은 (1) 보완대체의사소통 이해하기, (2) 다양한 $\mathrm{AAC}$ 도구 살펴보기, (3) AAC로 의사소통능력 향상하기, (4) 가정에서 쉽게 $\mathrm{AAC}$ 를 활용하는 팁, (5) $\mathrm{AAC}$ 지원정책 알아보기로 구성된 40 분의 프로그램으로 설계하였으며 여기에 질의응답 시간을 추가하였다. 부모 교육이 AAC 인식에 미치는 영향을 살펴보기 위해, 그리 고 부모의 인식 변화 정도와 교육 프로그램에 대한 만족도 간의 상관관계가 있는지를 살펴보기 위해 AAC 인식 관련 설문지와 교육 프 로그램 만족도 설문지를 개발하였다. 결과: $t$-test와 ANCOVA 분석 결과 AAC 인식에 관한 모든 설문 항목의 평균 점수가 교육 후 증가 하였고 교육 전후의 점수 차이는 모두 유의한 것으로 나타났다. Spearman 상관계수는 .443으로 만족도 점수와 AAC 인식 변화 간에 중 간 정도의 양적 상관관계가 있는 것으로 나타났다. 논의 및 결론: 본 연구는 부모교육이 AAC에 대한 부모의 인식에 긍정적인 영향을 미친다는 것을 보여주었다. 특히 아동이 $\mathrm{AAC}$ 를 사용하기 위해서는 온전한 인지능력을 갖춰야 한다는 잘못된 인식에 대해 가장 큰 변 화가 관찰되었다. $\mathrm{AAC}$ 에 대한 인식 개선과 관련 정보 및 기기 사용 기회의 제공에 중점을 둔 부모교육 프로그램이 긍정적인 인식 변화 를 이끌어 낸 것으로 보인다.

핵심어: 보완대체의사소통, 부모 교육, 인식

본 논문은 제 1 저자(김상민)의 석사학위논문의 일부를 수정 및 보완한 것임.

\section{참고문헌}

김경양, 박은혜 (2012). 가족-중심 보완대체의사소통(AAC) 중재가 자폐범주성 장애아동의 의사소통 능력과 가족 인식에 미치는 영향. 자폐성장애연 구, $12(1), 51-72$.

김정연, 박은혜 (2003). 중도 뇌성마비아동의 의사소통 기술 증진을 위한 AAC 대화상대자 훈련. 특수교육, 2(1), 37-58.

박한빛, 이주연, 박현주 (2020). 복합적인 의사소통 요구를 지닌 아동 부모의 AAC 포기 경험과 지원 요구. 보완대체의사소통연구, 8(2), 51-75.

박현주 (2020). 복합적인 의사소통 요구를 지닌 아동의 AAC 중재에 대한 부모의 경험 및 수용 요인 탐색. Communication Sciences \& Disorders, 25(2), 318-333.

박현주 (2021). "6개월까지는 계속 물음표였어요." 복합적인 의사소통 요구를 지닌 아동 부모의 AAC 수용 과정. Communication Sciences \& Disorders, 26(1), 120-136.

신정미, 이수향 (2016). 보완대체의사소통(AAC)에 대한 중도장애 학생 부모의 인식 조사. 보완대체의사소통연구, 4(2), 1-18.

오혜정 (2018). 장애자녀의 보완 대체의사소통(AAC) 활용에 대한 부모의 인식 및 지원요구에 관한 사례연구 한국청각언어장애교육연구, 9(2), 175-196. 임장현, 박은혜, 구정아 (2013). 보완대체의사소통(AAC) 중재 서비스에 대한 발달장애인 부모의 요구분석. 특수교육, 12(3), 309-332.

\section{ORCID}

김상민(제1저자, 대학원생 https://orcid.org/0000-0001-6619-9209); 박현주(공동저자, 교수 https://orcid.org/0000-0002-3868-6381); 신상은(교신저자, 교수 https://orcid.org/0000-0003-0148-7829) 